Suvremena psihologija 19 (2016), 2, 149-163

Izvorni znanstveni rad - UDK 159.922.6

DOI: $10.21465 / 2016-$ SP-192-02

\title{
RODITELJSKO ZADOVOLJSTVO, GENERATIVNOST I USPJEŠNO STARENJE
}

\author{
Ivana Tucak Junaković \\ Sveučilište u Zadru, Odjel za psihologiju \\ Obala kralja Petra Krešimira IV. br. 2, 23000 Zadar \\ itucak@unizd.hr \\ Marina Nekić \\ Sveučilište u Zadru, Odjel za psihologiju \\ Obala kralja Petra Krešimira IV. br. 2, 23000 Zadar \\ marina@unizd.hr \\ Neala Ambrosi-Randić \\ Sveučilište Jurja Dobrile u Puli, \\ Odjel za interdisciplinarne, talijanske i kulturološke studije \\ Zagrebačka 30, 52100 Pula \\ nambrosi@unipu.hr
}

\begin{abstract}
Sažetak
Uspješno starenje je višedimenzionalan konstrukt, ali konsenzus u pogledu njegovih komponenti i operacionalne definicije još nije postignut. U ranijim su istraživanjima ispitane njegove brojne determinante i korelati, ali istraživanja roditeljstva i generativnosti ili brige za dobrobit mlađih generacija u kontekstu uspješnog starenja zasada su vrlo rijetka. Stoga je provedeno istraživanje s ciljem ispitivanja povezanosti i doprinosa roditeljskog zadovoljstva i generativnosti starijih osoba njihovu uspješnom starenju.

U istraživanju su sudjelovala 444 starija roditelja u dobi od 60 do 95 godina iz različitih dijelova Hrvatske. Tri dimenzije roditeljskog zadovoljstva (zadovoljstvo sobom kao roditeljem, svojom djecom i odnosima s njima) ispitane su po jednim pitanjem za svaku. Generativnost je ispitana adaptiranom Loyola skalom generativnosti, a uspješno starenje Skalom samoprocjene uspješnog starenja.

Rezultati su pokazali da sudionici daju visoke procjene na sve tri dimenzije roditeljskog zadovoljstva. Rezultati na skali uspješnog starenja bili su značajno povezani $\mathrm{s}$ ispitanim dimenzijama roditeljskog zadovoljstva i s generativnošću. Nadalje, poka-
\end{abstract}

Zahvala: Autorice zahvaljuju Elizabeth A. Phelan na korisnim sugestijama i mogućnosti korištenja njezinih materijala u svrhu ispitivanja uspješnog starenja. 
zalo se da, nakon kontrole sociodemografskih varijabli, generativnost, zadovoljstvo sobom kao roditeljem i odnosima s vlastitom odraslom djecom značajno doprinose uspješnom starenju sudionika istraživanja.

Rezultati ovoga istraživanja upućuju na važnost brige za mlađe generacije i vlastite doprinose društvu te roditeljskog zadovoljstva i u starijoj dobi za uspješno nošenje s promjenama povezanima sa starenjem.

Ključne riječi: roditeljsko zadovoljstvo, generativnost, uspješno starenje

\section{UVOD}

Produživanje očekivanog životnog vijeka i udjela starijih osoba u populaciji razvijenih zemalja zadnjih desetljeća potaknulo je interes za istraživanje koncepta uspješnog starenja. Uspješno starenje je, bez sumnje, višedimenzionalan konstrukt, ali konsenzus u pogledu komponenti koje uključuje i njegove operacionalne definicije još nije i vjerojatno neće tako skoro biti postignut.

Biomedicinski pristup uspješnom starenju, čiji je najpoznatiji predstavnik Roweov i Kahnov model (Rowe i Kahn, 1987), ističe važnost dobroga zdravlja i očuvanih funkcionalnih sposobnosti za uspješno starenje. Psihosocijalni i laički pristupi (npr. Bowling, 2006; Bowling i Dieppe, 2005) nadopunjuju biomedicinski isticanjem važnosti varijabli subjektivne i psihološke dobrobiti te pozitivnih socijalnih odnosa za uspješno starenje, i to čak $i$ kod starijih osoba narušenoga zdravlja.

Temeljem analize 84 različita istraživanja, jedan noviji sustavan pregled operacionalnih definicija uspješnog starenja otkrio je čak 105 mjera ovoga konstrukta (Cosco, Prina, Perales, Stephan i Brayne, 2014). Oko 90\% ovih mjera temeljilo se na biomedicinskom pristupu, iako Cosco i sur. (2014) zaključuju da su komponente psihosocijalnog i laičkog pristupa sve više zastupljene. Ovisno o operacionalnoj definiciji uspješnog starenja, postotak onih koji uspješno stare u ovim se istraživanjima kretao u velikom rasponu, i to između manje od 1 pa sve do preko $90 \%$ sudionika (Cosco i sur., 2014).

Dok je uspješno starenje u Hrvatskoj zasada malo istraživano (Ambrosi-Randić i Plavšić, 2008; Tucak Junaković i Nekić, 2016), u mnogim su stranim istraživanjima zahvaćeni njegovi brojni potencijalni prediktori i korelati. Najčešće je ispitivan i empirijski potvrđen doprinos zdravstvenih varijabli, čimbenika povezanih sa stilom života i funkcionalnog stanja uspješnom starenju (Depp i Jeste, 2006; Meng i D'Arcy, 2014; Ng, Broekman, Niti, Gwee i Kua, 2009; Vahia, Thompson, Depp, Allison i Jeste, 2012). U porastu su i ona istraživanja koja ispituju povezanost između uspješnog starenja i različitih aspekata psihosocijalnog funkcioniranja, primjerice, zadovoljstva životom (Meng i D'Arcy, 2014), optimizma (Cosco, Stephan i Brayne, 2015; Vahia i sur., 2012), socijalnih odnosa i društvene uključenosti (Cosco i sur., 2015; Ng i sur., 2009; Pruchno, Wilson-Genderson, Rose i Cartwritght, 2010) i dr. S druge strane, iznenađuje nedostatak istraživanja odnosa različitih aspekata roditeljstva i generativnosti s uspješnim starenjem. 
Generativnost ili "briga za stvaranje i vođenje sljedeće generacije" (Erikson, 1984, str. 240) važno je razvojno obilježje srednje odrasle dobi. Međutim, pokazalo se da generativnost, koja se može promatrati i kao relativno stabilna crta ličnosti, nastavlja biti važna i u starijoj dobi (Fisher, 1995; Warburton, McLaughlin i Pinsker, 2006). Nakon Eriksona, konstrukt generativnosti je dosta proširen u teorijskim razmatranjima različitih autora (Bradley, 1997; McAdams i de St. Aubin, 1992; Stewart i Vandewater, 1998 i dr.). McAdams i de St. Aubin (1992) predložili su model prema kojem generativnost uključuje unutarnju želju i kulturalne zahtjeve za generativnošću koji zajedno potiču generativnu brigu, opisanu kao svjesnu zaokupljenost dobrobiti sljedeće generacije (McAdams i de St. Aubin, 1992). Višedimenzionalni konstrukt generativnosti, prema ovom modelu, nadalje uključuje i vjeru u smislenost ljudskog djelovanja, predanost generativnim ciljevima, konkretno generativno djelovanje te generativnu priču kojom odrasla osoba daje smisao vlastitim generativnim naporima. Od svih navedenih komponenti u istraživanjima se najčešće ispituje generativna briga kao središnja komponenta modela koja se često i poistovjećuje sa samim konstruktom generativnosti.

Generativna nastojanja starijih osoba mogu pridonijeti samoprihvaćanju, pozitivnoj evaluaciji ranijeg života i konačnoj integraciji ega i doživljaju smisla života (Carlson, Seeman i Fried, 2000; James i Zarrett, 2005; Warburton i sur., 2006). Nadalje, može se pretpostaviti da generativnost starijih osoba, potičući ih na različite aktivnosti, pridonosi očuvanju ili poboljšanju njihova tjelesnog i mentalnog zdravlja te većoj uključenosti u život zajednice, kao i drugim važnim aspektima uspješnog starenja, ovisno o tome kako ga se definira. Velik je broj istraživanja potvrdio pozitivne odnose između različitih aspekata generativnosti (npr. generativna briga, generativno djelovanje) i tjelesnog i mentalnog zdravlja te varijabli subjektivne $i$ psihičke dobrobiti (Ackerman, Zuroff i Moskowitz, 2000; de St. Aubin i McAdams, 1995; Grossbaum i Bates, 2002; Keyes i Ryff, 1998; Morfei, Hooker, Carpenter, Mix i Blakeley, 2004). Pri tome se subjektivna dobrobit odnosi na tzv. hedonističku komponentu dobrobiti i uključuje konstrukte kao što su zadovoljstvo životom, sreća te pozitivna ili negativna čuvstva. S druge strane, psihološka dobrobit uključuje mnogo više od samog zadovoljstva i sreće. Ona se prvenstveno odnosi na tzv. eudemonističku komponentu dobrobiti koja uključuje samoprihvaćanje, aktualizaciju vlastitih potencijala, ostvarenje vlastite prave prirode, osobni rast, smisao života i sl. (Ryan i Deci, 2001; Ryff i Keyes, 1995).

Mali se broj istraživanja bavio odnosom između generativnosti i uspješnog starenja kao šireg i obuhvatnijeg konstrukta u odnosu na samo zdravlje ili samu subjektivnu ili psihološku dobrobit. U jednom od rijetkih istraživanja generativnosti u kontekstu uspješnog starenja, Versey, Stewart i Duncan (2013) utvrdile su značajnu povezanost generativnih preokupacija s uspješnim starenjem kod visokoobrazovanih žena u ranim 60-im godinama života, i to ne samo u jednoj točki mjerenja nego i tijekom desetogodišnjeg razdoblja. 
Roditeljstvo je zasigurno jedan od najuobičajenijih oblika izražavanja generativnih težnji, iako se one šire i na druge životne domene izvan brige za vlastitu djecu prema brizi za mlađe generacije općenito, društvo u kojem živimo i svijet kakav ćemo za sobom ostaviti. Subjektivni doživljaj roditeljstva te roditeljsko zadovoljstvo, kao njegova komponenta, češće su istraživani u ranijim fazama obiteljskog ciklusa, kada su djeca u roditeljskom domu (Belsky, 1984; Delmore-Ko, Pancer, Hunsberger i Pratt, 2000; Lupton, 2000; Ljubetić, 1998; Sabatelli i Waldron, 1995 $\mathrm{i}$ dr.). S druge strane, roditeljsko zadovoljstvo u razdoblju tzv. praznog gnijezda, odnosno u starijih roditelja odrasle djece, rjeđe je bilo predmet istraživačkog zanimanja. U istraživanjima odnosa starijih roditelja i njihove odrasle djece može se primijetiti preusmjeravanje interesa s roditeljske brige za djecu na brigu odrasle djece o ostarjelim i onemoćalim roditeljima. Ipak, roditeljstvo i u starijih osoba, iako najčešće lišeno tereta aktivne roditeljske uloge, ostaje važan aspekt života koji snažno utječe na njihovu dobrobit. Rezultati ranijih istraživanja pokazali su da roditelji i nakon što im djeca napuste roditeljski dom ostaju usmjereni na djecu, nastoje očuvati bliske kontakte s njima, a odnos s djecom ostaje važan izvor njihove životne sreće i zadovoljstva (DeVries, Hostler i Watson, 2002, prema Čudina-Obradović i Obradović, 2006; Lehr i Thomae, 1987). Stoga se može pretpostaviti da roditeljsko zadovoljstvo starijih osoba doprinosi i njihovu uspješnom starenju, kao širem konstruktu u odnosu na varijable subjektivne dobrobiti.

$\mathrm{S}$ obzirom na generalni nedostatak istraživanja roditeljstva i generativnosti u kontekstu uspješnog starenja, a posebice u Hrvatskoj, provedeno je istraživanje s glavnim ciljem ispitivanja povezanosti i doprinosa različitih aspekata roditeljskog zadovoljstva i generativnosti objašnjenju individualnih razlika u uspješnom starenju u uzorku starijih osoba, nakon kontrole doprinosa sociodemografskih varijabli. Pretpostavljeno je da će i roditeljsko zadovoljstvo, kao ključan aspekt životnog zadovoljstva, i generativne preokupacije starijih osoba biti značajni pozitivni korelati i prediktori uspješnog starenja.

\section{METODA}

\section{Sudionici i postupak}

Rezultati prikazani u ovom radu dobiveni su u okviru šireg istraživanja nekih odrednica uspješnog starenja u starijih osoba iz različitih dijelova Hrvatske, točnije iz 17 županija. Za potrebe ovoga rada analizirani su podaci prikupljeni na prigodnom izvaninstitucionalnom uzorku od 444 starije osobe, u dobi od 60 do 95 godina, od kojih 188 muškaraca i 256 žena. Uzeti su podaci samo onih sudionika, od njih ukupno 479, koji su bili roditelji, što je, uz dob, bio i glavni kriterij odabira 
Tablica 1. Sociodemografska obilježja sudionika istraživanja $(N=444)$

\begin{tabular}{|c|c|c|}
\hline Varijabla & & $M(S D)$ \\
\hline dob & & $69,3(7,05)$ \\
\hline \multirow[t]{2}{*}{ broj djece } & & $2,2(0,84)$ \\
\hline & Kategorija & $N(\%)$ \\
\hline \multirow[t]{2}{*}{ spol } & muški & $188(42)$ \\
\hline & ženski & $256(58)$ \\
\hline \multirow[t]{3}{*}{ stupanj obrazovanja } & završena ili nezavršena osnovna škola & $126(28,3)$ \\
\hline & srednja škola & $219(49,4)$ \\
\hline & viša ili visoka škola & $99(22,3)$ \\
\hline \multirow[t]{5}{*}{ bračno stanje } & samci & $7(1,6)$ \\
\hline & u braku & $286(64,5)$ \\
\hline & nevjenčana zajednica & $9(2,0)$ \\
\hline & razvedeni & $24(5,4)$ \\
\hline & udovci & $118(26,5)$ \\
\hline \multirow{6}{*}{$\begin{array}{l}\text { veličina kućanstva/ } \\
\text { s kim žive }\end{array}$} & sami & $77(17,4)$ \\
\hline & $\mathrm{s}$ bračnim partnerom & $188(42,3)$ \\
\hline & samo s djecom & $40(9)$ \\
\hline & s bračnim partnerom i djecom & $77(17,4)$ \\
\hline & u proširenoj obitelji & $61(13,7)$ \\
\hline & s nekom drugom osobom & $1(0,2)$ \\
\hline \multirow[t]{3}{*}{ mjesto življenja } & grad & $275(62)$ \\
\hline & manje mjesto & $59(13,3)$ \\
\hline & selo & $110(24,7)$ \\
\hline \multirow[t]{2}{*}{ religioznost } & da & $330(74,4)$ \\
\hline & ne & $114(25,6)$ \\
\hline
\end{tabular}

sudionika. Broj njihove djece varirao je od 1 do 6 , ali većina je imala dvoje djece $(\operatorname{Mod}=2)$. Osnovna sociodemografska obilježja sudionika istraživanja prikazana su u Tablici 1.

Korištenjem metode snježne grude, sudionike su za istraživanje regrutirali sami istraživači i studenti Sveučilišta u Zadru i Sveučilišta Jurja Dobrile u Puli, posebno instruirani u primjeni upitnika. Podaci su prikupljani individualno, uz pomoć upitnika koji su sudionici popunjavali samostalno u prisutnosti ispitivača ili su oni čitali pitanja i tvrdnje upitnika, ako bi se sudionici za to odlučili. 


\section{Instrumenti}

Podaci su prikupljeni upitnikom koji je sadržavao veći broj pitanja i instrumenata, a za potrebe ovoga rada analizirat će se podaci prikupljeni pomoću sljedećih pitanja i skala:

1. Pitanja koja se odnose na sociodemografske varijable: spol, dob, stupanj obrazovanja (završena ili nezavršena osnovna škola, srednja škola, viša ili visoka škola), bračno stanje (samci, u braku, nevjenčana zajednica, razvedeni i udovci) i religioznost (ispitana pitanjem "Jeste li religiozni?" na koje su sudionici odgovarali pomoću "da" ili "ne")

2. Skala samoprocjene uspješnog starenja (Tucak Junaković i Nekić, 2016) nastala je na osnovi hrvatskoga prijevoda (Ambrosi-Randić i Plavšić, 2008) liste od 20 obilježja uspješnog starenja koju su predložili Phelan, Anderson, LaCroix i Larson (2004). Riječ je o obilježjima za koja su autori utvrdili da su se najčešće pojavljivala u dotadašnjoj literaturi o uspješnom starenju, a odnose se na različite aspekte uspješnog starenja, kao što su dobro funkcionalno stanje, tjelesno i mentalno zdravlje ili dobro socijalno funkcioniranje. Svaka od 20 originalnih tvrdnja (npr. "Imati prijatelje i obitelj koji su tu zbog mene" ili "Prilagođavati se promjenama koje su povezane sa starenjem") transformirana je u "ja" oblik (npr. "Imam prijatelje i obitelj koji su tu zbog mene" ili "Uspješno se prilagođavam promjenama koje su povezane sa starenjem"). Sudionici su pomoću skale od 5 stupnjeva procjenjivali koliko se svaka tvrdnja odnosi na njih, od 1 (uopće se ne odnosi na mene) do 5 (u potpunosti se odnosi na mene). Ukupan rezultat na skali upućuje na to u kojoj mjeri sudionici svoje starenje procjenjuju kao uspješno. Skala je pokazala jednofaktorsku strukturu i dobru pouzdanost. Koeficijent Cronbach alfa skale na ovom uzorku iznosio je 0,87 , a slične vrijednosti dobivene su i u ranijim primjenama ove skale (npr. Tucak Junaković i Nekić, 2016).

3. Tri dimenzije roditeljskog zadovoljstva ispitane su pomoću tri pitanja koja se odnose na:

a) Zadovoljstvo sobom kao roditeljem: "Koliko ste zadovoljni sobom kao roditeljem?"

b) Zadovoljstvo vlastitom djecom: "Koliko ste zadovoljni svojom djecom?"

c) Zadovoljstvo odnosima s vlastitom djecom: "Koliko ste zadovoljni odnosima koje imate sa svojom djecom?"

Sudionici su na ova tri pitanja odgovarali pomoću skale od pet stupnjeva, od 1 (potpuno sam nezadovoljan/na) do 5 (potpuno sam zadovoljan/na).

Iako se moglo pretpostaviti, što je i potvrđeno, da će ove tri dimenzije biti međusobno značajno povezane, ipak se radi o različitim dimenzijama čiji je zasebni doprinos uspješnom starenju bio u središtu interesa ovoga rada. Osim tri ispitane, postoje i druge dimenzije roditeljskog zadovoljstva koje nisu zahvaćene ovim istraživanjem. Iz ovih razloga procjene na ispitanim dimenzijama nisu kombinirane $u$ mogući ukupan rezultat koji bi se odnosio na ukupno roditeljsko zadovoljstvo. 
4. Adaptirana verzija (Lacković-Grgin, Penezić i Tucak, 2002) Loyola skale generativnosti (McAdams i de St. Aubin, 1992) ispituje generativnu brigu koja se odnosi na zaokupljenost dobrobiti mlađih generacija i vlastitim doprinosima tim generacijama i društvu u cjelini. Adaptirana verzija skale sadrži 17 tvrdnji (npr. "Osjećam da će moji doprinosi postojati i nakon moje smrti") na koje ispitanici odgovaraju pomoću skale od 5 stupnjeva, od 1 (uopće se ne odnosi na mene) do 5 (u potpunosti se odnosi na mene). Viši rezultat na skali upućuje na izraženiju generativnost. U ovom je istraživanju, slično kao i u ranijima (npr. Lacković-Grgin i sur., 2002), utvrđena jednofaktorska struktura skale i visoka pouzdanost tipa unutarnje konzistencije. Koeficijent unutarnje konzistencije Cronbach alfa u primjeni skale na ovom uzorku iznosio je 0,86 .

\section{REZULTATI}

Deskriptivne vrijednosti ispitanih varijabli i njihove korelacije prikazane su $\mathrm{u}$ Tablici 2.

Kolmogorov-Smirnovljev test je pokazao da, za razliku od rezultata na skalama generativnosti i uspješnog starenja, distribucije rezultata na mjerama roditeljskog zadovoljstva značajno odstupaju od normalne (Tablica 2). Ipak, zbog nepostoja-

Tablica 2. Deskriptivna statistika i korelacije ispitivanih varijabli $(\mathrm{N}=444)$

\begin{tabular}{lcccccc}
\hline VARIJABLE & Dob & ZR & ZD & ZO & G & US \\
\hline Dob & 1,00 & & & & & \\
Zadovoljstvo sobom kao & 0,09 & 1,00 & & & & \\
roditeljem (ZR) & & & & & & \\
Zadovoljstvo djecom (ZD) & 0,05 & $0,67^{* *}$ & 1,00 & & & \\
Zadovoljstvo odnosima s & 0,05 & $0,59^{* *}$ & $0,71^{* *}$ & 1,00 & & \\
djecom (ZO) & $-0,03$ & $0,26^{* *}$ & $0,18^{* *}$ & $0,24^{* *}$ & 1,00 & \\
Generativnost (G) & $-0,06$ & $0,34^{* *}$ & $0,27^{* *}$ & $0,37^{* *}$ & $0,60^{* *}$ & 1,00 \\
Uspješno starenje (US) & 69,3 & 4,2 & 4,3 & 4,2 & 3,6 & 3,7 \\
$M$ & 7,06 & 0,71 & 0,76 & 0,77 & 0,62 & 0,57 \\
$S D$ & $60-95$ & $1,00-5,00$ & $1,00-5,00$ & $1,00-5,00$ & $1,58-5,00$ & $1,40-5,00$ \\
Raspon & & $-1,11$ & $-1,51$ & $-1,14$ & $-0,27$ & $-0,48$ \\
Asimetričnost (SKW) & & 2,70 & 3,06 & 2,08 & $-0,19$ & 0,49 \\
Spljoštenost (KTS) & & $0,28^{* *}$ & $0,27^{* *}$ & $0,25^{* *}$ & 0,05 & 0,06 \\
Kolmogorov-Smirnovljev & & & & & & \\
test (K-S) & & & & & & \\
\hline
\end{tabular}

${ }^{*} p<0,05,{ }^{* *} p<0,01$ 
nja ekstremnih vrijednosti indeksa asimetričnosti i spljoštenosti, može se smatrati opravdanim korištenje parametrijske statistike (Kline, 2011).

Rezultati na svim mjerama pomaknuti su prema višim vrijednostima, što je osobito izraženo za rezultate na dimenzijama roditeljskog zadovoljstva.

Sve ispitane varijable, uz izuzetak korelacija dobi s ostalim varijablama, značajno su pozitivno korelirale. Te su se korelacije kretale od niskih do umjereno visokih. Najviše su povezanosti utvrđene između triju dimenzija roditeljskog zadovoljstva. Rezultati na skali uspješnog starenja bili su značajno povezani sa sve tri dimenzije roditeljskog zadovoljstva i, u najvećoj mjeri, s generativnošću.

Tablica 3. Rezultati hijerarhijske regresijske analize s uspješnim starenjem kao kriterijem i sociodemografskim varijablama, roditeljskim zadovoljstvom i generativnošću kao prediktorima

\begin{tabular}{|c|c|c|}
\hline Prediktori & $\beta$ & $(\beta)$ \\
\hline \multicolumn{3}{|l|}{ 1. korak } \\
\hline \multicolumn{3}{|l|}{ Sociodemografske varijable } \\
\hline Spol & 0,09 & \\
\hline Dob & $-0,03$ & \\
\hline Stupanj obrazovanja (OŠ, SŠ, VSŠ) & $0,11^{*}$ & $(0,12 * *)$ \\
\hline Partnerska veza ${ }^{\text {a }}$ (1-da, 2-ne) & $-0,00$ & \\
\hline Religioznost (1-da, 2-ne) & 0,03 & \\
\hline $\mathrm{R}^{2}$ & 0,020 & \\
\hline$F_{(5,438)}$ & 1,85 & \\
\hline \multicolumn{3}{|l|}{ 2. korak } \\
\hline \multicolumn{3}{|l|}{ Roditeljsko zadovoljstvo } \\
\hline Zadovoljstvo sobom kao roditeljem & $0,26 * *$ & $\left(0,14^{* *}\right)$ \\
\hline Zadovoljstvo djecom & $-0,11$ & \\
\hline Zadovoljstvo odnosima s djecom & $0,30 * *$ & $(0,22 * *)$ \\
\hline$\Delta R^{2}$ & $0,175^{* *}$ & \\
\hline$R^{2}$ & $0,195^{* *}$ & \\
\hline$F_{(8,435)}$ & $13,21 * *$ & \\
\hline \multicolumn{3}{|l|}{ 3. korak } \\
\hline Generativnost & $0,52 * *$ & $(0,52 * *)$ \\
\hline$\Delta R^{2}$ & $0,245 * *$ & \\
\hline$R^{2}$ & $0,440 * *$ & \\
\hline$F_{(9,434)}$ & $37,86 * *$ & \\
\hline
\end{tabular}

${ }^{*} p<0,05,{ }^{* *} p<0,01 ;(\beta)$ - $\beta$-koeficijent u završnom koraku

${ }^{\mathrm{a}} 1$ - brak i nevjenčana zajednica; 2 - nikada vjenčani, razvedeni i udovci 
Provjerili smo i moguće razlike s obzirom na spol u ispitanim varijablama i pokazalo se da one nisu bile značajne $(p>0,05)$ ni za jednu ispitanu varijablu.

Kako bi se ispitao doprinos dimenzija roditeljskog zadovoljstva i generativnosti objašnjenju individualnih razlika u uspješnom starenju, nakon kontrole doprinosa sociodemografskih varijabli, provedena je hijerarhijska regresijska analiza (Tablica 3). Prikazane su vrijednosti $\beta$-koeficijenata prediktora u onom koraku u kojem su uvedeni u analizu te, u zagradi, značajni $\beta$-koeficijenti u zadnjem koraku analize.

Uključene sociodemografske varijable zajedno nisu imale značajan doprinos objašnjenju kriterijske varijable. Za potrebe ove analize varijabla koja se izvorno odnosila na bračni status je zbog velikog nerazmjera u broju sudionika u pojedinim potkategorijama (npr. mali broj onih u nevjenčanoj zajednici, onih koji nikada nisu bili u braku, kao i razvedenih), podijeljena u dvije kategorije. U prvu su ušle osobe u partnerskoj vezi, tj. one koje žive u braku i u nevjenčanoj zajednici $(N=295)$, dok su u drugu kategoriju ušle osobe koje u trenutku ispitivanja nisu bile u partnerskoj vezi, tj. udovci, razvedeni i nikad vjenčani $(N=149)$. Među ispitanim sociodemografskim varijablama jedino je stupanj obrazovanja imao značajan zaseban doprinos uspješnom starenju, pri čemu su oni obrazovaniji, prema vlastitoj procjeni, uspješnije starjeli. Tri dimenzije roditeljskog zadovoljstva, uvedene u drugom koraku, značajno su pridonijele objašnjenju individualnih razlika u uspješnom starenju. Postotak objašnjene varijance porastao je za 17,5\%, pri čemu su se zadovoljstvo sobom kao roditeljem i zadovoljstvo odnosima s djecom pokazali značajnim pozitivnim prediktorima uspješnog starenja. Generativnost, uvedena u zadnjem koraku analize, povećala je postotak objašnjene varijance uspješnog starenja, nakon kontrole sociodemografskih varijabli i roditeljskog zadovoljstva, za čak $24,5 \%$, sugerirajući da osobe koje su generativnije i uspješnije stare. Svi prediktori zajedno objasnili su značajnih $44 \%$ varijance individualnih razlika u uspješnom starenju.

\section{RASPRAVA}

Istraživanje je provedeno $\mathrm{s}$ glavnim ciljem ispitivanja doprinosa roditeljskog zadovoljstva i generativnosti uspješnom starenju u uzorku starijih osoba iz različitih krajeva Hrvatske. Roditeljsko zadovoljstvo je, uz zahtjeve i stres roditeljske uloge te osjećaj roditeljske kompetencije, jedna od dimenzija subjektivnog doživljaja roditeljstva (Sabatelli i Waldron, 1995). Roditeljsko zadovoljstvo uključuje veći broj dimenzija, kao što su zadovoljstvo odnosom između roditelja i djeteta, zadovoljstvo vlastitom uspješnošću kao roditelja, zadovoljstvo potporom bračnog partnera vlastitoj roditeljskoj ulozi, zadovoljstvo ponašanjem djeteta, zadovoljstvo samim sobom kao roditeljem (Čudina-Obradović i Obradović, 2006). Mi smo se u ovom istraživanju odlučili usmjeriti na aspekte roditeljskog zadovoljstva starijih osoba koje smatramo najvažnijima. To su zadovoljstvo samima sobom kao roditeljima, zadovoljstvo vlastitom djecom, što može uključivati zadovoljstvo roditelja time u 
kakve su im osobe djeca izrasla, zadovoljstvo njihovim karakternim i drugim osobinama, njihovom uspješnošću i sl., te zadovoljstvo odnosima koje stariji roditelji imaju s vlastitom odraslom djecom. Za većinu je odraslih osoba upravo roditeljstvo najčešći način na koji iskazuju svoje generativne težnje ili nastojanja da doprinesu dobrobiti mlađih generacija. Pretpostavili smo da će svaka od ove tri zasebne, ali međusobno povezane dimenzije roditeljskog zadovoljstva, kao i generativnost značajno zasebno doprinijeti uspješnom starenju sudionika ovoga istraživanja.

Rezultati istraživanja koji zasigurno zahtijevaju detaljnije objašnjenje odnose se na visoke procjene dobivene na tri ispitane dimenzije roditeljskog zadovoljstva. One vjerojatno nisu samo odraz stvarno visokog zadovoljstva starijih osoba u roditeljskoj ulozi, visokog zadovoljstva vlastitom djecom i odnosima koje ostvaruju s njima, nego barem dijelom i idealizirane slike o vlastitoj uspješnosti u roditeljskoj ulozi, o vlastitoj djeci i odnosima s njima, kao i želje i nastojanja starijih roditelja da ovi ispitani aspekti roditeljstva uistinu budu što kvalitetniji. Uzorak ovoga istraživanja je izvaninstitucionalni uzorak osoba koje žive uglavnom u vlastitom domu i koje svoje zdravlje procjenjuju relativno dobrim (Napomena: zdravstveni status je ispitan pomoću samoprocjene tjelesnog i mentalnog zdravlja te pitanja koje se odnosi na (ne)postojanje kroničnih bolesti; ti podaci upućuju na relativno dobro zdravlje sudionika istraživanja, ali, zbog ograničenog opsega rada, nisu ovdje prikazani). Ipak, riječ je o starijim osobama za koje se stoga može pretpostaviti da će im se s godinama funkcionalno i zdravstveno stanje pogoršavati i da će zbog toga zahtijevati sve veću pomoć vlastite djece. To je još jedan od mogućih razloga zbog kojega su starije osobe motivirane vidjeti sebe kao dobre roditelje, a vlastitu djecu (koja su rezultat vlastitog uspješnog roditeljstva), kao dobre i uspješne osobe s kojima žele održati kvalitetne odnose i na koje se, u slučaju potrebe, mogu osloniti. U skladu s ovim, ranija su istraživanja pokazala da roditeljstvo i u stadiju praznog gnijezda nastavlja biti ključan aspekt života starijih roditelja koji ostaju fokusirani na živote svoje odrasle djece, nastoje očuvati bliske odnose s njima, a odnos s djecom i roditeljsko zadovoljstvo i dalje snažno utječe na njihovu dobrobit (DeVries i sur., 2002, prema Čudina-Obradović i Obradović, 2006; Lehr i Thomae, 1987). Uz to, starije osobe su često sklone davati visoke procjene svoga roditeljskog zadovoljstva, te pretjerano hvaliti svoju djecu kako bi uzvisili svoje roditeljstvo, dok bliskost sa svojom odraslom djecom uzimaju kao dokaz vlastitog uspjeha u roditeljskoj ulozi pa često tu bliskost procjenjuju većom nego njihova odrasla djeca (Lacković-Grgin, 2011).

U pogledu odnosa između triju dimenzija roditeljskog zadovoljstva, generativnosti i uspješnog starenja, pokazalo se da su sve ove varijable međusobno značajno pozitivno povezane. Najveće povezanosti utvrđene su između generativnosti i uspješnog starenja, te između pojedinih dimenzija roditeljskog zadovoljstva, što je i očekivano jer su sve tri aspekti istog nadređenog konstrukta roditeljskog zadovoljstva. Te korelacije ipak nisu bile toliko visoke pa se može zaključiti da se radi o različitim, iako povezanim, dimenzijama. Od svih varijabli uključenih u skupinu 
potencijalnih prediktora uspješnog starenja najveći doprinos imala je generativnost. U skladu s očekivanjima, usmjerenost na dobrobit mlađih generacija i nastojanje da se ostavi značajan trag u zajednici doprinose uspješnom suočavanju s promjenama koje su povezane s godinama. Malobrojna ranija istraživanja odnosa generativnosti i uspješnog starenja također su potvrdila doprinos generativnosti uspješnom starenju (Carlson i sur., 2000; Fisher, 1995; Versey i sur., 2013). Primjerice, Fisher (1995) je na osnovi podataka dobivenih intervjuiranjem starijih osoba utvrdio da one generativnost smatraju važnom za uspješno starenje. Izgleda da starije osobe svoje generativne aktivnosti u obitelji i društvenoj zajednici vide kao način prenošenja vlastitih znanja $i$ iskustava mlađim generacijama, što pozitivno doprinosi njihovoj psihološkoj dobrobiti pa tako i iskustvu uspješnog starenja (Warburton i sur., 2006). Pretpostavljamo da generativne preokupacije starijih osoba doprinose njihovu uspješnom starenju na način da ih potiču na različite aktivnosti, primjerice, na veći društveni angažman, pomaganje vlastitoj djeci i unucima, bavljenje različitim hobijima itd. Takve aktivnosti bi onda mogle pridonijeti očuvanju dobrog zdravstvenog i funkcionalnog statusa starijih osoba, njihovim dobrim socijalnim odnosima, samoprihvaćanju, osjećaju životne svrhe i smisla itd., a sve ili neke od ovih varijabli, ovisno o načinu njegove operacionalne definicije, mogu se smatrati komponentama širokog konstrukta uspješnog starenja.

Među dimenzijama roditeljskog zadovoljstva, zadovoljstvo sobom kao roditeljem i zadovoljstvo odnosima s vlastitom djecom značajno su pridonijeli uspješnom starenju. Osobe koje smatraju da su bile ili jesu uspješne u svojoj roditeljskoj ulozi te koje procjenjuju da su njihovi odnosi s djecom kvalitetni vjerojatno su stoga $i$ zadovoljnije životom i imaju generalno veću dobrobit, što se onda može odraziti i na njihovo uspješnije starenje. Prema našem saznanju, nema komparabilnih nalaza drugih studija o roditeljstvu u kontekstu uspješnog starenja. Međutim, kako je već spomenuto, neka su istraživanja pokazala da i u stadiju tzv. roditeljstva bez djece roditeljsko zadovoljstvo osoba starije dobi ostaje snažan izvor njihove sreće i zadovoljstva (DeVries i sur., 2002, prema Čudina-Obradović i Obradović, 2006; Lehr i Thomae, 1987), a ove se i druge varijable dobrobiti prema mnogim konceptualizacijama uspješnog starenja smatraju njegovim važnim komponentama.

$\mathrm{U}$ pogledu doprinosa ispitane skupine sociodemografskih varijabli, pokazalo se da, uz izuzetak stupnja obrazovanja, one nemaju značajan doprinos objašnjenju individualnih razlika u samoprocjeni uspješnog starenja. Rezultati ranijih istraživanja u ovom pogledu nisu konzistentni. Tako je u nekima utvrđeno da je više starijih osoba za koje se može smatrati da uspješno stare među ženama (Ng i sur., 2009), osobama koje žive u braku (Bowling i Illife, 2006; Meng i D’Arcy, 2014; Pruchno i sur., 2010), obrazovanijima (Ng i sur., 2009) i religioznima (Ng i sur., 2009; Pruchno i sur., 2010), dok u drugim istraživanjima nisu utvrđene značajne razlike s obzirom na ove sociodemografske varijable (Depp i Jeste, 2006). Od svih sociodemografskih varijabli koje smo uključili u naše istraživanje, samo je obrazovanje značajno pridonijelo uspješnom starenju. Možemo pretpostaviti da starije osobe višeg stupnja 
obrazovanja vjerojatno imaju bolje osobne resurse kao što su adaptivnije strategije suočavanja sa stresorima povezanima sa starenjem, kao i bolje financijske resurse, koji onda olakšavaju uspješno starenje. Velik broj ranijih istraživanja potvrdio je povezanost mlađe dobi s uspješnijim starenjem (Depp i Jeste, 2006; Meng i D'Arcy, 2014; Ng i sur., 2009; Pruchno i sur., 2010), što se može objasniti u prvom redu boljim zdravljem i funkcionalnim sposobnostima mlađih ljudi. U ovom istraživanju takav odnos nije utvrđen, što je vjerojatno posljedica, s obzirom na dob, relativno homogenog uzorka koji je uključivao samo osobe starije životne dobi.

U pogledu ograničenja istraživanja, prvenstveno treba spomenuti njegov transverzalni nacrt, korištenje mjera koje se većinski oslanjaju na samoprocjenu i mali varijabilitet rezultata na mjerama roditeljskog zadovoljstva koje su uključivale samo po jednu česticu. U budućim bi istraživanjima roditeljskog zadovoljstva starijih osoba u kontekstu uspješnog starenja ili drugih konstrukata bilo dobro koristiti osjetljivije i pouzdanije mjere roditeljskog zadovoljstva starijih roditelja odrasle djece s većim brojem tvrdnji kojima bi se detaljnije ispitale njegove pojedine dimenzije. Svakako bi bilo poželjno u longitudinalnim istraživanjima ispitati stvarne razvojne promjene u doživljaju roditeljstva, generativnosti i uspješnom starenju te njihove međuodnose kroz različite točke mjerenja.

Usprkos navedenim nedostacima, provedeno istraživanje upozorilo je na važnost generativnih preokupacija i roditeljskog zadovoljstva starijih osoba za njihovo uspješno suočavanje s promjenama povezanima sa starenjem. Vidimo ga kao početni korak i mogući poticaj daljnjim istraživanjima odnosa među ovim varijablama.

\section{LITERATURA}

Ackerman, S., Zuroff, D. C., Moskowitz, D. S. (2000). Generativity in midlife and young adults: Links to agency, communion, and subjective well-being. International Journal of Aging and Human Development, 50, 17-41.

Ambrosi-Randić, N., Plavšić, M. (2008). Uspješno starenje. Pula: Društvo psihologa Istre, Istarska županija, Sveučilište Jurja Dobrile u Puli.

Belsky, J. (1984). The determinants of parenting: A process model. Child Development, 55, 83-96.

Bowling, A. (2006). Lay perceptions of successful ageing: findings from a national survey of middle aged and older adults in Britain. European Journal of Ageing, 3, 123-136.

Bowling, A., Dieppe, P. (2005). What is successful ageing and who should define it? British Medical Journal, 331, 24-31.

Bowling, A., Iliffe, S. (2006). Which model of successful aging should be used? Baseline findings from a British longitudinal survey of ageing. Age and Ageing, 35, 607-614.

Bradley, C. L. (1997). Generativity - stagnation: Development of a status model. Developmental Review, 17, 262-290.

Carlson, M. C., Seeman, T., Fried, L. P. (2000). Importance of generativity for healthy aging in older women. Aging - Clinical and Experimental Research, 12, 132-140. 
Cosco, T. D., Prina, A. M., Perales, J., Stephan, B. C. M., Brayne, C. (2014). Operational definitions of successful aging: a systematic review. International Psychogeriatrics, 26(3), 373-381.

Cosco, T. D., Stephan, B. C. M., Brayne, C. (2015). Validation of an a priori, index model of successful aging in a population-based cohort study: the successful aging index. International Psychogeriatrics, 27(12), 1971-1977.

Čudina-Obradović, M., Obradović, J. (2006). Psihologija braka i obitelji. Zagreb: Golden marketing-Tehnička knjiga.

De St. Aubin, E., McAdams, D. P. (1995). The relations of generative concern and generative action to personality traits, satisfaction/happiness with life and ego development. Journal of Adult Development, 2(2), 99-112.

Deep, C. A., Jeste, D. V. (2006). Definitions and predictors of successful aging: a comprehensive review of larger quantitative studies. The American Journal of Geriatric Psychiatry, 14, 6-20.

Delmore-Ko, P., Pancer, S. M., Hunsberger, B., Pratt, M. (2000). Becoming a parent: The relation between prenatal expectations and postnatal experience. Journal of Family Psychology, 14, 625-640.

Erikson, E. (1984). Childhood and society. London: Triad Paladin.

Fisher, B. J. (1995). Successful aging, life satisfaction, and generativity in later life. International Journal of Aging and Human Development, 41(3), 239-250.

Grossbaum, M. F., Bates, G. W. (2002). Correlates of psychological well-being at midlife: The role of generativity, agency and communion, and narrative themes. International Journal of Behavioral Development, 26(2), 120-127.

James, J. B., Zarrett, N. (2005). Ego integrity in the lives of older women: A follow-up of mothers from the Sears, Maccoby, and Levin (1951) patterns of child rearing study. Journal of Adult Development, 12(4), 155-167.

Keyes, C. L. M., Ryff, C. D. (1998). Generativity in adult lives: Social structural contours and quality of life consequences. U D. P. McAdams i E. de St. Aubin (ur.), Generativity and Adult Development: How and Why We Care for the Next Generation (str. 227-263). Washington, D.C.: APPA Press.

Kline, R. B. (2011). Principles and practice of structural equation modeling. New York: The Guilford Press.

Lacković-Grgin, K. (2011). Doživljaj i praksa roditeljstva u različitim životnim razdobljima. Društvena istraživanja, 20(4), 1063-1083.

Lacković-Grgin, K., Penezić, Z., Tucak, I. (2002). Odnos generativnosti i drugih komponenti ličnosti Eriksonova modela u osoba mlađe, srednje i starije odrasle dobi. Suvremena psihologija, 5, 9-30.

Lehr, U., Thomae, H. (1987). Formen seelischen Alterns (Ergebnisse der Bonner Gerontologischen Langschnittstudie-BOLSA). Stuttgart, Enke Verlag.

Lupton, D. (2000). A love/hate relationship: The ideals and experiences of first-time mothers. Journal of Sociology, 36, 50-63.

Ljubetić, M. (1998). Samoprocjena kompetentnosti roditelja za roditeljsku ulogu. Napredak, 139, 290-297. 
McAdams, D. P., de St. Aubin, E. (1992). A theory of generativity and its assessment through self-report, behavioral acts and narrative themes in autobiography. Journal of Personality and Social Psychology, 62(6), 1003-1015.

Meng, X., D'Arcy, C. (2014). Successful Aging in Canada: Prevalence and predictors from a population-based sample of older adults, Gerontology, 60(1), 65-72.

Morfei, M. Z., Hooker, K., Carpenter, J. Mix, C., Blakeley, E. (2004). Agentic and communal generative behavior in four areas of adult life: Implications for psychological wellbeing. Journal of Adult Development, 11(1), 55-58.

Ng, T. P., Broekman, B. F. P., Niti, M., Gwee, X., Kua, E. H. (2009). Determinants of successful aging using a multidimensional definition among Chinese elderly in Singapore. The American Journal of Geriatric Psychiatry, 17(5), 407-416.

Phelan, E. A., Anderson, L. A., LaCroix, A. Z., Larson, E. B. (2004). Older adults' views of "successful aging" - How do they compare with researchers' definitions? Journal of the American Geriatric Society, 52(2), 211-216.

Pruchno, R. A., Wilson-Genderson, M., Rose, M., Cartwritght, F. (2010). Successful aging: early influences and contemporary characteristics. The Gerontologist, 50(6), 821-833.

Rowe, J. W., Kahn, R. L. (1987). Human aging: usual and successful. Science, 237, 143-149.

Ryan, R. M., Deci, E. L. (2001). On happiness and human potentials: a review of research on hedonic and eudaimonic well being. Annual Review of Psychology 2001, 52, 141-166.

Ryff, C. D., Keyes, C. L. M. (1995.). The structure of psychological well-being revisited. Journal of Personality and Social Psychology, 69, 719-727.

Sabatelli, R. M., Waldron, R. J. (1995). Measurement issues in the assessment of the experience of parenthood. Journal of Marriage and the Family, 57, 969-980.

Stewart, A. J., Vandewater, E. A. (1998). The course of generativity. U D. P. McAdams i E. de St. Aubin (ur.), Generativity and Adult Development: How and Why We Care for the Next Generation (str. 75-100). Washington, D.C.: APPA Press.

Tucak Junaković, I., Nekić, M. (2016). Skala samoprocjene uspješnog starenja. U I. Tucak Junaković, I. Burić, V. Ćubela Adorić, A. Proroković i A. Slišković (ur.), Zbirka psihologijskih skala i upitnika, svezak 8 (str. 37-43). Zadar: Sveučilište u Zadru.

Vahia, I. V., Thompson, W. K., Depp, C. A., Allison, M., Jeste, D. V. (2012). Developing a dimensional model for successful cognitive and emotional aging. International Psychogeriatrics, 24(4), 515-523.

Versey, H. S., Stewart, A. J., Duncan, L. E. (2013). Successful aging in late midlife: The role of personality among college-educated women. Journal of Adult Development, 20, $63-75$.

Warburton, J., McLaughlin, D., Pinsker, D. (2006). Generative acts: Family and community involvement of older Australians. International Journal of Aging and Human Development, 63(2), 115-137. 


\title{
PARENTAL SATISFACTION, GENERATIVITY AND SUCCESSFUL AGING
}

\begin{abstract}
Successful aging is a multidimensional construct, but there is no consensus regarding its components and operationalization. In previous research, many determinants and correlates of successful aging were examined, but research on the role of parenting and generativity or a concern for the welfare of the next generation, in the context of successful aging was rather scarce so far. Therefore, we conducted a study with the purpose of examining the relationship and contribution of parental satisfaction and generativity to successful aging of older parents.

The subjects in the study were 444 older parents, 60 to 95 years old, from various parts of Croatia. Three dimensions of participants' parental satisfaction were measured using one question for each. Generativity was examined by an adapted version of the Loyola Generativity Scale and successful aging by the Self-Rated Successful Aging Scale.

Results have shown that subjects scored high on all three dimensions of parental satisfaction. Results on the successful aging scale correlated significantly with the examined dimensions of parental satisfaction and with generativity. Furthermore, results have shown that after controlling for sociodemographic variables, participants' generativity and satisfaction with themselves as parents and with the relations they have with their adult children significantly contribute to successful aging.

The findings of the study indicate the importance of generative concern for the next generation and one's lasting contribution to society, as well as the importance of parental satisfaction of older parents for their successful adaptation to age related changes.
\end{abstract}

Key words: parental satisfaction, generativity, successful aging 
